\title{
Comments
}

\section{PER SE RULES AND SECTION 5 OF THE FEDERAL TRADE COMMISSION ACT}

Section 5 of the Federal Trade Commission Act provides that "unfair methods of competition in commerce . . . are declared illegal."1 The Federal Trade Commission has primary responsibility for giving content to this vague statutory standard. ${ }^{2}$ This Comment will examine the relationship between the FTC's interpretation of section 5 and the antitrust policies enforced through the Sherman $\mathrm{Act}^{3}$ and the Clayton Act. ${ }^{4}$

Part I reviews the historical development and recent expansion of the scope of section 5. It focuses on the failure of the decisions to clarify when injury to competition must be proved by thorough economic analysis and when such injury may be presumed by using a per se rule. Part II first discusses critically the Supreme Court's 1966 decision in FTC v. Brown Shoe Co. ${ }^{5}$ This discussion followed by a brief consideration of the FTC's apparent attempt to apply the virtually unlimited mandate it received in Brown Shoe to the problem of vertical mergers in the cement industry. The conclusion suggests some policies that the FTC should follow in developing and applying per se rules under section 5 to harmonize that section with the other antitrust laws.

\section{I}

THE EXPANDING SCOPE OF SECTION 5 OF THE FTC ACT

The Federal Trade Commission Act was enacted in 1914, almost concurrently with the Clayton Act. Both statutes reflected congressional concern over the Supreme Court's holding in Standard Oil Co. v. United States $^{8}$ that section 1 of the Sherman Act outlawed only unreasonable restraints of trade. Businessmen declared that this decision made it impossible for them to know whether a proposed action was legal; Wilsonian Democrats complained that the Court had eviscerated the statute. ${ }^{7}$ Al-

138 Stat. 719 (1914), as amended, 15 U.S.C. \& 45 (1964) [hereinafter referred to as the FTC Act].

2 See Atlantic Ref. Co. Va FTC, 381 U.S. 357, 367 (1965).

${ }^{3} 26$ Stat. 209 (1890), as amended, 15 U.S.C. $\$$ 1-2 (1964) [hereinafter referred to as the Sherman Act].

438 Stat. 730 (1914), as amended, 15 U.S.C. $\$ \S 12-27$ (1964) [hereinafter referred to as the Clayton Act].

5384 U.S. 316 (1966).

B 221 U.S. 1 (1911).

7 Votaw, Antitrust in 1914: The Climate of Opinion, 24 A.B.A. AnTrreust Secrion 14, 20-21 (1964). 
though both groups favored more specific prohibitions, neither the Clayton Act nor the FTC Act fully met their desires. ${ }^{8}$

The specificity of the Clayton Act prohibitions is blurred by the necessity of showing that the behavior will probably "substantially lessen competition." Congress may well have hesitated to pass legislation containing detailed hists of per se offenses for fear of stifling efficient production and the development of new forms of distribution..$^{10}$ As a result, the language of the Clayton Act, like that of the Sherman Act, required the courts to examine in detail a complex set of social and economic relationships, and to master somewhat sophisticated economic theory. ${ }^{11}$ The courts have since characterized a number of practices as per se violations of the Sherman or Clayton Acts, thus eliminating the necessity for a detailed investigation of economic effects. ${ }^{12}$

The FTC Act represents a different approach: a specialized administrative agency operating under a broad grant of power to define continually new categories of offenses. This power permits the FTC to supplement the prohibitions of the Clayton Act, which it enforces concurrently with the Justice Department. ${ }^{13}$

In framing section 5 of the FTC Act, Congress recognized both the difficulty of specifying all the anti-competitive practices that then existed and the likelihood that businessmen would invent new ones. It sought to give the FTC a fairly free hand in defining and attacking such practices. ${ }^{14}$ But the early cases restricted this freedom by requiring the FTC to show either that the challenged practice would tend to create a monopoly or that it was so clearly unfair as to amount to a fraud. ${ }^{15}$

\footnotetext{
8 Id. at 25-27.

9 Clayton Act, $\S \S 2,3,7$.

10 See Markham, The Federal Trade Commission's Use of Economics, 64 Conum. L. Rev. 405, 405-08 (1964).

11 See United States v. Grinnell Corp., 236 F. Supp. 244, 247 (D.R.I. 1964) (Wyzanski, J.), aff'd and modified, 384 U.S. 563 (1966).

12 See discussion note 28 infra.

1338 Stat. 734, 736 (1914), as amended, 15 U.S.C. $\S \S 21,25$ (1964).

14 FTC v. Gratz 253 U.S. 421, 436 (1920) (Brandeis, J., dissenting); see S. REP. No. 597, 63d Cong., 2d Sess. 13 (1914); H.R. Rep. No. 1142, 63d Cong., 2d Sess. 19 (1914).

15 In FTC v. Gratz, 253 U.S. 421 (1920), the Supreme Court set aside the FTC's order prohibiting respondent from tying the sale of jute bags to the purchase of its steel wire, because the complaint had not alleged that respondent had monopoly power in the steel wire market. The Court went on to emphasize that it and not the Commission had the responsibility for determining the scope of the phrase "unfair methods of competition," which was "clearly inapplicable to practices never heretofore regarded as opposed to good morals because characterized by deception, bad faith, fraud or oppression. . . ." Id. at 427. The Commission's order was also set aside in FTC v. Curtis Publishing Co., 260 U.S. 568 (1923), in which the Court held that the defendant's extensive network of exclusive agency contracts was not in itself sufficient evidence from which to infer a tendency to monopoly, and that the contracts were not unfair because such marketing methods had "long been recognized as proper and unobjectionable practice." Id. at 582.
} 
Not until 1934 in FTC v. R. F. Keppel \& Bros, Inc. ${ }^{16}$ did the Court accept the idea that the Commission could characterize accepted business practices as unfair and attack them regardless of whether they were likely to develop into the anti-competitive proportions of a Sherman Act violation. ${ }^{17}$ But, while denying that "the Commission may prohibit every unethical competitive practice regardless of its particular character or consequences, $" 18$ the Court declined to suggest what circumstances might be relevant in permitting the use of section 5 against new types of unfair practices. The case demonstrated the Court's new respect for the Commission's expertise, but it gave little indication of how broadly section 5 could be read when applied to behavior not related to tort notions of unfair competition. ${ }^{19}$

\section{A. The Incipiency Rationale}

In two important cases in the 1940's, Fashion Originators' Guild v. $F T C^{20}$ and FTC v. Cement Institute, ${ }^{21}$ the Court emphasized the theory that section 5 was designed to deal with putative violations of the Clayton and Sherman Acts in their "incipiency." 22 The Court observed in Fashion Orginators' Guild that the boycott attacked under section 5 of the FTC Act resembled the exclusive dealing agreements forbidden by section 3 of the Clayton Act. ${ }^{23}$ The Court added that the "combination in its entirety [was] well within the inhibition of the policies declared by the Sherman Act," ${ }^{24}$ although the offense was incipient because the FTC did not find that the Guild had monopoly power. ${ }^{25}$ In Cement Institute the Court declared that the basing point pricing system employed by the defendants was analogous to a Sherman Act price fixing conspiracy. ${ }^{26}$

The incipiency interpretation of section 5 has been criticized as improper where the analogy is to a Clayton Act violation, ${ }^{27}$ because it lias

16291 U.S. 304 (1934).

17 Id. at 310 . The respondent's violation consisted of selling candy in coin-operated machines, which delivered variable amounts of candy. It was this "gambling" aspect of the arrangement which was attacked as unfair.

18 Id. at 314.

19 See generally 1 Cartaman, Unfatr Compettuion and Trademarks $\$ \$ 6.1,6.2(f)$ (2d ed. 1950); Prosser, TorTs $\$ 124$, at 979-81 (3d ed. 1964).

20312 U.S. 457 (1941).

21333 U.S. 683 (1948).

22312 U.S. at 466 ; see 333 U.S. at 694 ; Butterick Publishing Co. v. FTC, 85 F.2d 522 (2d Cir. 1936); accord, FTC v. Motion Picture Advertising Serv. Co., 344 U.S. 392 (1953); cf. FTC v. Raladam Co., 283 U.S. 643,647 (1931).

23312 U.S. at 465.

24 Ibid.

${ }^{25}$ Ibid., see Millinery Creator's Guild, Inc. v. FTC, 312 U.S. 469, 472 (1941).

26 See 333 U.S. at 706-12.

27 Howery, Utilization by the FTC of Section 5 of the Federal Trade Commission Act as an Antitrust Law, 5 ANrTTrust Buct. 151 (1960). 
been held that the Clayton Act was intended to deal with incipient Sherman Act offenses. ${ }^{28}$ The use of section 5 to reach incipient Clayton-type offenses would virtually eliminate the required showing that the conduct in question would probably "substantially lessen competition." The practices referred to $\mathrm{m}$ the Clayton Act would thus be converted into per se offenses. ${ }^{30}$

In both Fashion Originators' Guild and Cement Institute, however, the incipiency rationale was not necessary to the decision, since the same behavior that violated section 5 of the FTC Act was also held to violate the Clayton Act. ${ }^{31}$ This was not the case in FTC v. Motion Picture Advertising Serv. Co. ${ }^{32}$ because the complaint was brought solely under section $5 .^{33}$ The majority stated that certain exclusive dealing contracts

28 Standard Fashion Co. v. Magrane-Houston Co., 258 U.S. 346, 355-57 (1922); accord, FTC v. Raladam Co., 283 U.S. 643, 647 (1931).

20 Sections 3 and 7 of the Clayton Act employ this standard to determine whether the degree of injury to competition in a given case is illegal.

30 Per se violations consist of those activities which are conclusively presumed to have the necessary anti-competitive effect. Economic analysis is not required to establish that they are "in restraint of trade or commerce," Sherman Act $\S 1$, or that they will "probably substantially lessen competition or tend to create a monopoly," Clayton Act \$§ 2, 3, 7. Although Congress may incorporate such presumptions into legislation, as it did in $\S 8$ of the Clayton Act, which prohibits certain interlocking directorates (See Standard Oil Co. v. United States 337 U.S. 293, 311-12 (1949) [hereinafter referred to as Standard Stations]), most per se rules have been created by the Supreme Court in an effort to avoid the exhaustive inquiry into actual economic effect required in Sherman Act rule-of-reason cases. The Court will create such a presumption where it has been convinced by experience in a number of cases that the practice invariably has the prohibited anti-competitive effect. United States v. Northern Pac. R.R., 356 U.S. 1, 5 (1957); cf. White Motor Co. v. United States, 372 U.S. 253 (1963).

On the other hand, "a rule of reason standard requires the courts to assay the economic consequences of business behavior and to ban only behavior which is unreasonable in purpose or effect." Kessler \& Stern, Competition, Contract, and Vertical Integration, 69 YaIE L.J. 1, 22 (1959). "Unreasonable" usually refers to how restrictive the effect of the practice will be and not to whether the firm had non-predatory business reasons for engaging in it. The latter is relevant, however, where the charge involves an attempt to monopolize under $\S 2$ of the Sherman Act.

A compromise between the per se and rule of reason approaches emerged in Standard Slations. Section 3 of the Clayton act required a showing that the requirements contracts there in question would probably result in substantial anti-competitive effect. The Court held that this effect could be presumed where the practice had foreclosed competitors from a substantial share of the retail outlets, and it was not necessary to decide if the industry would have been more competitive had other marketing devices been used.

81312 U.S. at $464 ; 333$ U.S. at 725-26.

32344 U.S. 392 (1953).

$\mathbf{3 3}$ Clayton Act $\S 3$ was not applicable both because it applies anly to commodities and because it refers to the seller conditioning the sale on the buyer's agreement not to buy from other sellers. Here the oligopoly buyers were imposing the restriction on the sellers. The specificity with which offenses are defined in the Clayton Act often makes that act inapplicable; hence the Justice Department is forced to fall back on the Sherman Act to 
had "sewed up" seventy-five per cent of the market and thereby produced a degree of foreclosure which "falls within the prohibitions of the Sherman Act." 34 The Court's holding that the agreements violated section 5 of the FTC Act was therefore based on the standards of the Sherman Act and not on the incipiency rationale..$^{35}$

None of the foregoing cases set forth any definition of the threshold level of injury to competition which would make the challenged behavior an incipient violation of the Clayton or Sherman Acts. In all three of these cases, however, the prohibition of the behavior in question was buttressed by ample evidence that it would probably substantially lessen competition. Furthermore, the behavior was analogous to some per se offense, so that sufficient anti-competitive effect could be presumed. ${ }^{36}$ So long as the use of section 5 to reach incipient Clayton and Sherman Act violations was confined to such cases as these, the failure to define the threshold of incipiency posed no problems.

\section{B. The Grand Union Doctrine}

Another method of expanding the scope of section 5 has been approved by several circuit courts, ${ }^{37}$ although the Supreme Court has yet to rule directly on its validity. These courts take the view that section 5 can be applied to conduct which the Clayton Act cannot reacli because of some technical hmitation arising from the manner in which the offense is described. In Grand Union Co. v. FTC, ${ }^{38}$ the court held that a buyer's inducement of discriminatory promotional allowances violated section 5 . Section 2(d) of the Robinson-Patman Act prohibits the granting of such allowances, ${ }^{39}$ but by its terms applies only to the seller. The court declared

prosecute offenses resembling Clayton Act violations. See, e.g., Northern Pac. Ry. v. United States, 356 U.S. 1 (1958) (tying agreement in sale of land).

34344 U.S. at 395 .

35 Kessler \& Stern, supra note 30, at 59.

36 The boycott in Fashion Originators' Guild was directed at "style pirates" who copied defendants' dresses and sold them at lower prices. 312 U.S. at 461 . This was analogous to the price-fixing conspiracy in United States v. Socony-Vacuum Oil Co., 310 U.S. 150 (1940), which was held illegal per se. Id. at $223-24$ \& n.59. The basing point pricing system enlployed in Cement Institute was likewise held to be analogous to a price-fixing conspiracy and therefore illegal per se. 333 U.S. at 708-16. The exclusive dealing contracts in Motion Picture Advertising Serv. Co. are not analogous to a per se offense, but it appears that these contracts gave the defendant sufficient power to exclude competition and control prices to qualify as a monopoly under the Sherman Act. See Kessler \& Stern, supra note 30, at 56-59; cf. American Tobacco Co. v. United States, 328 U.S. 781, 810-11 (1946).

37 Grand Union v. FTC, 300 F.2d 92 (2d Cir. 1962); American News Co. v. FTC, 300 F.2d 104 (2d Cir.), cert. denied, 371 U.S. 824 (1962); Giant Food Inc. v. FTC, 307 F.2d 184 (D.C. Cir. 1962), cert. denied, 372 U.S. 910 (1963).

38300 F.2d 92 (2d Cir. 1962).

3949 Stat. 1527 (1936); 15 U.S.C. § 13(d) (1964). 
that the buyer's acts had violated the spirit, if not the letter, of section 2 (d), and that congressional omission of buyers from the section seemed "more 'inadvertent' than 'studious." "40

The defendant-buyer in Grand Union had persuaded a number of its suppliers to pay for the entire cost of renting a large illuminated billboard in Times Square. The Grand Union Co. had the right to use the sign twenty-five per cent of the time. ${ }^{11}$ Since the suppliers had not entered into similar arrangements with other buyers, they had clearly violated the requirement of section 2 (d) that promotional allowances be made available to all buyers in proportion to the amount of their purchases. In fact, the FTC had successfully prosecuted some of the suppliers involved in the Grand Union scheme. ${ }^{42}$

The dissenting judge attacked the majority's characterization of the omission from section 2(d) of any reference to the buyer as inadvertent. He noted that the majority itself had recognized that the principal purpose of the Robinson-Patman Act was to control the economic power of large chain stores; and, although the legislative history was silent on the ommission of buyers from section 2(d), it was hardly likely that such a central concern would be inadvertently overlooked. This argument is buttressed by the fact that Congress did impose limitations in section 2 (f) which apply to the buyer. That section forbids "any person ... knowingly to induce or receive a discrimination in price which is prohibited by this section." 43 It appears that section $2(f)$ would cover inducement not only of direct price discounts, but also of indirect discounts by having the seller pay for the buyer's facilities in violation of section 2(d). Nevertheless, the FTC did not proceed against Grand Union under section 2(f), probably because the Supreme Court had held, in FTC v. Automatic Canteen Co. ${ }^{44}$ that a violation of section 2(f) was not a per se offense. To establish a prima facie case that the buyer "knowingly" induced the seller to violate price discrimination proscriptions of section 2(a), the FTC was required in Automatic Canteen to show that the buyer knew that the seller's price discrimination could not be justified by the defenses of cost justification or meeting competition contained in section 2(b). Applying the same reasoning, the FTC would have had to show in Grand Union that the buyer knew the seller's payments to him were not made proportionately available to others.

In Grand Union the FTC avoided this burden by using section 5 of

40300 F.2d at 96.

41 The arrangement was later modified so that Grand Umion received the cash equivalent of $25 \%$ of the rentals. See 300 F.2d at 94 .

42 E.g., Swanee Paper Corp. v. FTC, 291 F.2d 833 (2d Cir. 1961).

4349 Stat. 152 (1936); 15 U.S.C. $\S 13(f)$ (1964),

44346 U.S. 61 (1953). 
the FTC Act to combine the restriction of section 2(f) on buyers with the per se character of $2(d)$ to create a new offense under the mantle of section 5 of the FTC Act. The majority characterized this process as merely overcoming technical limitations in the Clayton Act, ${ }^{45}$ but this argument is unconvincing. The Commission's approach, endorsed by the court of appeals, created a new per se offense, eliminating the economic justifications for price discrimination which are built into the statute. ${ }^{46}$ Although the result of the case may be in harmony with the general policy of the Robinson-Patman Act, the rationale of the case required an extension of the substantive law.

The FTC's approach in Grand Union was greeted by most commentators with disapproval ${ }^{47}$ because it would open the door to a wholesale replacement of the technical himitations of the Robinson-Patman Act and similar limitations in other sections of the Clayton Act by the vague spirit of section 5. Cases following Grand Union, however, applied the doctrine only in closely analogous situations. ${ }^{48}$

\section{The Atlantic-Goodyear Case}

The Supreme Court's 1965 opinion in the Atlantic-Goodyear case ${ }^{48}$ illustrated the influence of both the incipiency rationale and the Grand Union doctrine. Unfortunately, the opinion failed to place any limits on these two approaches to section 5. It created the impression that they could be used to frame a per se rule regardless of whether the conduct in question was analogous to a per se violation of the Sherman or Clayton Acts.

\section{The Dual Rationale: Per Se Illegality and Constructive Coercion}

In Atlantic-Goodyear the FTC complained that a contract between Atlantic and the Goodyear Tire and Rubber Co. constituted an unfair method of competition in violation of section 5. Under the contract, Atlantic sponsored the sale of Goodyear-supplied tires, batteries, and accessories (referred to in the trade as TBA business) to Atlantic's "independent" wholesalers and retail dealers. Atlantic received a sales commission of 7.5 per cent on wholesalers' purchases and ten per cent on

45300 F.2d at 98 .

46 See Oppenheim, Guides to Harmonizing Section 5 of the Federal Trade Commission Act with the Sherman and Clayton Acts, 59 MICH. L. Rev. 821 (1961); Rahl, Does Section 5 of the Federal Trade Commission Act Extend the Clayton Act?, 5 ANTITRUST BuLI. 533 (1960).

47 Rahl, supra note 45, at 540; Handler, Recent Antitrust Developments, 71 YaLE L.J. 75, 91-92 (1962). But see Oppenheim, supra note 45, at 841-43.

48 See cases cited in note 37 supra; Max Factor, Inc., Trade REg. Rep. II 16992 (FTC July 22, 1964).

40 Atlantic Ref. Co. v. FTC, 381 U.S. 357 (1965). 
dealers' purchases. The Commission's order prohibited Atlantic from entering into similar contracts with any supplier of TBA; Goodyear was likewise forbidden to so contract with any marketing oil company. The Seventh Circuit upheld the order ${ }^{50}$ and the Supreme Court affirmed. ${ }^{51}$

Atlantic employed a number of techniques to encourage its dealers to buy only sponsored TBA. ${ }^{.2}$ These techniques succeeded largely because the dealers were, in the words of the court of appeals, "ostensibly . . . independent businessmen; but behind the legalistic façade of independence .... the service station dealer is more of an economic serf than a businessman free to purchase the TBA of his choice." ${ }^{23}$ This serfdom resulted not only from the disparity in size and financial strength between Atlantic and any of its distributors, but also from the short-term leases or equipment rental contracts between them. If a dealer insisted on purchasing non-sponsored TBA, the company could simply refuse to renew his lease. For this reason, "suggestions" on the part of Atlantic were usually quite sufficient to bring errant dealers into line. ${ }^{64}$ The trial examiner also found several instances of open coercion." Although he limited his initial order to forbidding sucl coercion, the Commission's final order, upheld intact by the Court, enjoined the sales commission plan itself as an unfair method of competition. The Court felt that the agreement gave Atlantic an incentive to use its economic power in one market to limit competition in another market. The effect, said the Court, was the same as if Atlantic and its wholesalers and dealers had entered into a tying agreement. ${ }^{56}$

The classical tying agreement consists of a sale of product $A$ (the tying product) on condition that the purchaser buy product $B$ (the tied product). ${ }^{57}$ The Atlantic-Goodyear agreement may be termed a quasitying agreement because Atlantic did not manufacture the tied product. The effectiveness of a tying agreement has been attributed to either the

${ }^{50}$ Goodyear Tire \& Rubber Co. v. FTC, 331 F.2d 394 (7th Cir. 1964), affd sub nom., Atlantic Ref. Co. v. FTC, 381 U.S. 357 (1965).

51 Atlantic Ref. Co. v. FTC, 381 U.S. 357 (1965).

52 The FTC trial examiner had found that the salient elements of the plan were as follows: Atlantic received monthly reports of Goodyear's TBA sales to Atlantic's distributors, and it contacted all those who bouglit from other sources to urge them to buy the sponsored products; Attantic "double-teamed" its field representatives with Goodyear salesmen to give the latter added impact when they called on Atlantic's distributors; Atlantic also permitted the dealer's customers to charge sponsored TBA purchases on their credit cards. Goodyear Tire \& Rubber Co., 58 F.T.C. 309, 314-15 (1962).

53 Goodyear Tire \& Rubber Co. v. FTC, 331 F.2d 394, 400 (7th Cir. 1964), aff'd sub nom., Atlantic Ref. Co. v. F'TC, 381 U.S. 357 (1965).

54381 U.S. at 366.

5558 F.T.C. at 316-19.

56381 U.S. at 370.

57 See, e.g., International Salt Co. v. United States, 332 U.S. 392 (1947). 
dominant market position of the tying products8 or its "desirability to consumers or ... umqueness in its attributes." ${ }^{259}$ The Court did not say that Atlantic had a dominant position in the industry, as in Standard Stations; $;^{\circ 0}$ nor did it suggest that Atlantic's products were unique or particularly desirable either to individual consumers or to Atlantic's dealers. ${ }^{61}$ The leverage for the tying product arose from Atlantic's systematic exploitation of the economic disparity between the parties.

This conclusion is evident from the Court's reliance on its 1964 decision in Simpson v. Union Oil Co. ${ }^{02}$ a case which involved the coercive use of consignment contracts as a device to impose retail price maintenance. The Court there conceded that the normal use of consignments, whereby an owner retains title to the article and authorizes the dealer to sell it at a price set by the owner, is perfectly legal. ${ }^{63}$ But when used as the basis of a vast distribution system, with the threat of cancellation of the dealers' leases as a sanction for selling below the authorized price, it deprives the dealers of "practically the only power they have to be wholly independent businessmen." ${ }^{\circ 4}$ In Atlantic-Goodyear the Court went further by asserting that this result does not depend on outright coercion. Once the small dealer had committed himself to Atlantic, and had spent time and money

58 Times-Picayune Publishing Co. v. United States, 345 U.S. 594, 611 (1953) ; accord, Northern Pac. Ry. v. United States, 356 U.S. 1 (1958), emphasizing that the dominant position does not have to reach monopoly proportions so long as there is "sufficient economic power to impose an appreciable restraint on free competition in the tied product." Id at 11. The Court also required that a "'not insubstantial' amount of interstate commerce ... [be] affected." Id. at 6, citing United States v. International Salt Co., 332 U.S. 392 (1947).

60 United States v. Loew's, Inc., 371 U.S. 38,45 (1962). See id. at 45 n.4.

Bo Standard Oil of California was the largest seller in the seven Western states in which it operated, with 23\% of the market (1946 figures). 337 U.S. 293, 295 (1949). Atlantic's proportion of sales in the seventeen state Eastern Seaboard area in which it operated was only $6.8 \%$ (1948 figures). 381 U.S. 357,363 n.4 (1965). The record does not indicate whether this share was sufficient to make Atlantic one of the leading firms in its market area. The Commission counsel supporting the complaint did not base his argument on Atlantic's share of the market. See 58 F.T.C. 309, 316 (1961) (Finding \#19, Initial Decision of Hearing Examiner). He was content to state dollar totals of sales and the number of distributors involved. Id. at 364. This evidence met the substantiality test of International Salt, but gives no indication of whether Atlantic had the requisite market power to impose tying agreements.

01 In a very narrow sense Atlantic's products might be termed "unique" because no other company sold products labeled "Atlantic"; but it is doubtful that the Court intended the "unique attributes" test to apply when there are virtually identical substitutes for the product on the narket. Cf. F.T.C. v. Borden Co., 383 U.S. 637 (1966). The Court's niodel was a popular motion picture, which bas no substitute, yet does not as a rule dominate the market for notion pictures. See United States v. Loew's Inc., 371 U.S. 38 (1962).

02377 U.S. 13 (1964).

${ }^{63}$ Id. at $17-18,21$.

04 Id. at $20-21$. 
in developing his business at a certain location, he could not afford to defy the company without risking a substantial loss in his investment in equipment and good will. ${ }^{65}$

The decision thus reflects a dual rationale. In part, the Court declares that the sales commission plan was analogous to a tying agreement, which is illegal per se. ${ }^{66}$ On the other hand, the Court substitutes a finding of constructive coercion for the requirement in Sherman Act cases that the tying product enjoy significant popularity in the market. ${ }^{67}$

The analysis adopted by the Court did not require it to engage in an economic analysis of the probable effects of the sales commission plan. Of course, if the sales commission system could be treated as illegal per se, there was no need for such economic analysis. However, the Commission was faced with the Supreme Court's decision in White Motor Co. v. United States. ${ }^{68}$ In that case, the Court held that when it has had no previous opportunity to assay the effects on competition of a novel form of activity, it will not declare that activity illegal per se. This decision requires that the actual and potential impact of the new practice be revealed by detailed findings of fact after a hearing on the merits. ${ }^{69}$ The theory of constructive coercion avoided this requirement.

\section{Two Alternative Theories}

The Atlantic-Goodyear decision would have been based on sounder grounds if the Commission had chosen either of two alternative theories to justify its attack on the sales commission plan. It would have been easy to establish that the agreement restrained a substantial volume of commerce in the tied product; this meets the Clayton standard of injury to coinpetition. ${ }^{70}$ Then, pointing out that the technical requirements of

65 Because he can operate efficiently on a smaller scale and with less capital, the distributor is commonly the weaker partner in a relationship of this kind. But a large retail chain may enjoy a dominant relationship with small manufacturers. See McDonald, Sears Makes It Look Easy, Fortune, May 1964, pp. 120, 125-27.

${ }^{06}$ See 381 U.S. at $369-71$.

07 E.g., United States v. Loew's, Inc., 371 U.S. 38 (1962) (tying product was popular motion picture, uniquely desirable to consumers); Northern Pac. Ry. v. United States, 356 U.S. 1 (1958) (choice mineral, agricultral and industrial land); United States v. International Salt Co., 332 U.S. 392 (1947) (patented salt dispensing machines).

68372 U.S. 253 (1963).

69 Klaus argues that the Commission's approach in its administrative hearings anticipated the requirements of White Motors. Klaus, Analysis of the Sales-Commission System of Tires, Batteries and Accessories Distribution in Retrospect: Answers for an Incisive Dissent, 44 TexAs L. REv. 890, 396-97 (1966). This view overlooks the Commission's failure to develop a consistent theory of per se illegality in accord with its analysis of the probable effects of the sales commission plan. See text accompanying notes 70-74 infra.

70 See Times-Picayune Publishing Co. v. United States, 345 U.S. 594, 608 (1953) (dictum). Turner, The Validity of Tying Arrangements Under the Antitrust Laws, 72 HARv. L. REV. 50, 58 (1958). 
section 3 of the Clayton Act had not been met because the seller of the tying product was a completely separate entity from the seller of the tied product (TBA), the Commission could have invoked the Grand Union doctrine to reach behavior which produced the same restrictive effect as behavior which was illegal per se under the statute.

Alternatively, the Commission could have followed a rule of reason approach. Under such an approach it would investigate the actual and probable effects of the sales commission plan in the tire industry. It is unfortunate that the Supreme Court's opinion does not contain a more satisfying analysis of the anti-competitive effects of the sales commission plan. Most of the data needed for such an analysis were present in the opinions of the Commission and the Seventh Circuit. Such an analysis would have focused less on the relationship between Atlantic and its distributors and more on the effects of the plan on the tire industry. The starting point would be the market position of the "Big Four" tire manufacturers-Goodyear, Firestone, Goodrich and U. S. Rubber-who collectively dominate the market. ${ }^{71}$ All four of these companies have sales commission plans which collectively cover all of the major oil companies and many of the sinaller ones. ${ }^{72}$ The plans require the TBA supplier to assume the risks of financing, warehousing, and distributing TBA to the entire network of an oil refiner's wholesalers and dealers; they also require the tire company to maintain a full hine of batteries and accessories. It is very difficult for smaller tire manufacturers to meet these requirements. Consequently, the widespread use of the sales commission system gives the "Big Four" a decisive advantage in access to the service

71 Klaus, supra note 69 , at 912 . It would have been helpful had the FTC found such facts as the share of the TBA market and the service station submarket controlled by the Big Four, and shown how this share increased as sales commission plans were adopted. Klaus takes the position, however, that it is sufficient to show that the dollar amount of trade restrained by the arrangement is substantial. This would be adequate to establish a Sherman Act violation if sufficient economic power to impose an effective tying agreement had already been established. Id. at 908-10 \& n.114. See Northern Pac. Ry. v. United States, 356 U.S. 1, 6 (1958); Times-Picayune Publishing Co. v. Umited States, 345 U.S. 594, 608-09 (1953). Moreover, the Supreme Court will accept sketchy evidence of market power; see United States v. Loew's, Inc., 371 U.S. 38, 45 (1962). When, as in AtlanticGoodyear, even this minimal standard is not met, the dollar total of trade affected by the sales commission plan does not in itself make the plan illegal under Sherman Act standards.

72 Klaus, supra note 69, at 912; cf. FTC v. Motion Picture Advertising Serv. Co., 344 U.S. 392 (1953). The complaint in this case was brought under $\S 5$, but the case was discussed by the Court in Sherman Act terms. Respondent's exclusive contracts covered only $40 \%$ of the market, but the Court stressed that respondent together with its three major competitors had "sewed up" $75 \%$ of the market. Id. at 395. There was no implication that this had resulted froni any combination or conspiracy among the four compames; the opinion suggests rather that the Court could not assess the actual effect of respondent's contracts without considering them in the context of the degree of concentration that prevailed in the industry. See Kessler \& Stern, supra note 30, at 55-59. 
station market. It would appear that the sale of TBA through service stations accounts for a substantial share of the replacement market, although the record does not indicate the percentage. In any event, the service station market exhibits sufficient peculiar characteristics to constitute a well defined submarket. ${ }^{73}$

The sales commission system is one of the principal means by which the major tire manufacturers maintain their predominant market power. If they accomplished this result by making sales directly to dealers, whose purchases reflected their own preferences, it would be unobjectionable. The sales commission agreement, however, tends to restrain trade because it gives the oil company an incentive to discourage the dealers from buying non-sponsored TBA. It must be assumed that this is the object of the sales commission agreement, for there does not appear to be any other reason why the tire manufacturer should be willing to pay such substantial commissions. The evidence would thus show a restrictive agreement which substantially lessens competition. The extent of injury to competition might not be sufficient to invoke the Sherman Afct. But the functioning of the sales commission was similar to that of a tying agreement and its effects would have been shown to be similar also. Under such circumstances, it would have been proper to invoke the incipiency rationale of section 5 of the FTC act to declare the plan illegal. ${ }^{74}$

\section{Constructive Coercion: A Misleading Theory}

The foregoing analysis does not require an investigation of the sources of Atlantic's constructive coercion over its dealers. The sales commission agreement should be judged by the anti-competitive effects it produced and not by an investigation of the psychology of the relationship between Atlantic and its dealers. The focus on Atlantic's use of constructive coercion was therefore unnecessary and misleading. The majority's use of this rationale led the dissenters to the conclusion that the prohibition of the sales commission plan was inconsistent with the FTC's apparent

73 See United States v. Sun Oil Co., 176 F. Supp. 715, 719 (E.D. Pa. 1959). Some of the characteristics that delineate service stations as a $\mathrm{TBA}$ submarket are specialization of vendors, distinct customer requirements and industry recognition of the submarket. See Klaus, supra note 69, at 907.

74 In addition to the injury to competition aniong tire manufacturers, the sales commission plan inhibited intrabrand competition. Various Goodyear wholesalers were made "supply points" for particular Atlantic dealers, and no other Goodyear wholesaler was permitted to sell to any Atlantic dealer who had been assigned to a supply point. The vertical establishnent of exclusive territories violates the Sherman Act if it curtails substantial existing intrabrand competition. See United States v. Arnold, Scbwinn \& Co., 237 F. Supp. 323, 342 (N.D. Ill. 1965), prob. juris. noted, 382 U.S. 936 (1965) (No. 611, 1965 Term; renumbered No. 25, 1966 Term). 
willingness to sanction an alternative method of marketing TBA known as purchase-resale.

While enjoining one form of vertical distribution arrangement, the FTC and the courts have suggested in some cases that another form might comply with the antitrust laws. ${ }^{75}$ Prior to 1951 , Atlantic purchased tires and batteries from independent manufacturers and resold them to its distributors. The FTC's final order expressly excepted direct distribution by Atlantic; ${ }^{76}$ this implies that such a distribution plan would be acceptable. Justices Stewart and Harlan, however, maintained in their dissent ${ }^{77}$ that if a purchase-resale plan is a permissible arrangement, an order prohibiting the sales commission plan is at best fatuous, because other TBA sellers would be equally foreclosed from the Atlantic dealer market under a purchase-resale plan. At worst, as Justice Goldberg's dissenting opinion points out, ${ }^{78}$ it gives an unfair advantage to those major oil companies which are strong enough to afford the capital investment necessary to set-up a purchase-resale plan.

There was substantial evidence in the record, however, to suggest that the anti-competitive effects of the sales commission plan were much greater than those of the purchase-resale plan. The sales commission plan could not be used by smaller TBA manufacturers, as they lacked the financial resources, the distribution network and the full product line which this system required. ${ }^{79}$ Under a purchase-resale plan, on the other hand, the oil company bears the financing and distribution expenses; it also has no incentive to buy all of its TBA from any one source regardless of price and quality. Smaller firms which can compete more efficiently in part of an oil company's trading area can secure a part of its business. In addition, the purchase-resale plan forces the oil company to pay more attention to the desires of the ultimate consumer. The oil company has a substantial investment in TBA inventory that it may not be able to sell profitably if it fails to meet consumer preferences. By contrast, under a sales commission system this risk is largely transferred to the TBA supplier.

It appears, therefore, that the purchase-resale plan will not, contrary

75 See Snap-On Tools Corp. v. FTC, 321 F.2d 825 (7th Cir. 1963). Compare Standard Stations, 337 U.S. 293, 310, suggesting that refiner might convert "independent stations" into either agents or wholly owned outlets, with United States v. Richfield Oil Corp., 99 F. Supp. 280, 289-94 (S.D. Cal. 1951), aff'd, 343 U.S. 922 (1952) (per curian).

7658 F.T.C. 309, 369 (1961) (Order No. 1). But see Klaus, supra note 67, at 916, pointing out that the Commission has warned that purchase-resale may also be illegal under some circumstances.

77381 U.S. at $378-79$.

78 Id. at $387-88$.

79 Klaus, supra note 69 , at $916-17$. 
to the fears of Justices Stewart and Harlan, foreclose the smaller TBA manufacturers to the same extent as would the sales commission plan. Justice Goldberg's assertion that purchase-resale would aid the larger oil companies against the smaller ones also seems incorrect. The oil companies which adopt purchase-resale plans are certainly not guaranteed a profit. Indeed, Atlantic abandoned its original purchase-resale plan precisely because it was not making enough money to justify the capital investment and risks involved. ${ }^{80}$ Implicit in Justice Goldberg's suggestion is the behef that a purchase-resale plan would enable those major oil companies adopting it to increase their share of gasoline sales. Admittedly, a motorist might be influenced in his selection of a service station by the knowledge that he could purchase his TBA requirements at the same time he bought gasoline. There is no evidence, however, to suggest that independent dealers would be incapable of maintaining an adequate supply of high quality TBA, without depending on an oil refiner to furnish these items. ${ }^{81}$

This analysis indicates that the purchase-resale plan poses less of a threat to competition than the sales commission plan. Paradoxically, however, the purchase-resale plan is more likely to generate constructive coercion simply because the oil company investment is substantial under the purchase-resale plan but inconsequential under the sales commission plan. True, the oil company might pay more attention to dealer preferences in selecting the brands to be included in a purchase-resale plan because those preferences would tend to reflect the preferences of the ultimate consumer. But once this selection had been made, the company would certainly seek to maximize dealer purchases of those particular brands, although it could not legally forbid purchases of other brands. ${ }^{82}$

To summarize, the sales commission plan could probably have been held illegal under either of two alternate theories. ${ }^{83}$ By focusing instead on whether Atlantic's relationship to its dealers amounted to a continuous coercion, the Supreme Court's opinion created a false and misleading issue.

The use of the coercion doctrine is dangerous for two reasons. First, it proves too much. The real issue is whether competition is being reduced; it may well be that a plan which involves a greater risk of coer-

80 See Goodyear Tire Co., 58 F.T.C. 309, 329-31 (1961).

81 Klaus, supra note 69, at 918.

82 Lessig v. Tidewater Oil Co., 327 F.2d 459, 467-70 (9th Cir.), cert. denied, 377 U.S. 993 (1964) ; Hammond Ford Inc. v. Ford Motor Co., 39 F.R.D. 604 (S.D.N.Y. 1966). See Standard Stations, 337 U.S. 293, 306-14 (1949).

${ }^{83}$ See text accompanying notes $70-74$ supra. 
cion will nevertheless have less harmful effects on competition. Second, it is too easy to water down the coercion standard in the same way that the conspiracy standard has been watered down in the vertical price maintenance cases. ${ }^{84}$ It is simple to find some weak form of "coercion" in any vertical relationship, ${ }^{85}$ and the result of making this finding determinative can be to prohibit business arrangements which would not be unlawful under any substantive standard. The truth of this becomes evident in examining the Supreme Court's 1966 decision which struck down the Brown Shoe Company franchise plan.

\section{II}

SECTION 5 AS AN INDEPENDENT SOURCE OF PER SE RULES

\section{A. FTC v. Brown Shoe $\mathrm{Co}^{86}$}

The method of analysis used in Atlantic-Goodyear, with its emphasis on "constructive coercion" was again employed in Brown Shoe. Brown Shoe Company furnished its franchise plan dealers with free business forms, group life insurance, merchandising assistance and rubber footwear (purchased in bulk and supplied at reduced prices); the dealers in turn agreed to concentrate their purchases in shoes made by Brown. The FTC had held that this arrangement was akin to a tying agreement, relying principally on evidence that a number of smaller shoe manufacturers had found it very difficult to make sales to former customers who had joined the franchise plan. ${ }^{87}$ The Eighth Circuit set aside the FTC's cease and desist order, primarily because there was no showing of either "sufficient economic power"88 or "uniqueness"88 in the tying product. The court also pointed out that dealers were free to carry competing products to some extent, to leave the program without suffering severe financial loss, and to buy from Brown without joining the plan. ${ }^{80}$

The Supreme Court reversed the decision of the court of appeals, thereby reinstating the Commission's order. The Court in a brief opinion did not discuss whether the Brown plan should be classified as a tying agreement or as some other recognized type of antitrust offense. It therefore never reached the question of whether the Brown plan

84 Compare Dr. Miles Medical Co. v. Park \& Sons Co., 220 U.S. 373 (1911), with United States v. Parke, Davis \& Co., 362 U.S. 29 (1960).

85 See Buxbaum, Boycotts and Restrictive Marketing Arrangements, 64 MicH. L. REv. $670,689-90(1966)$.

80384 U.S. 316 (1966) [hereinafter referred to as Brown Shoe].

87 Brown Shoe Co., Trade Reg. Rer. II 16316 (FTC, March 12, 1963).

88 Northern Pac. Ry. v. United States, 356 U.S. 1, 6 (1958).

89 United States v. Loew's, Inc., 371 U.S. 38, 45 (1962).

80 Brown Shoe Co. v. FTC, 339 F.2d 45 (8th Cir. 1964), rev'd, 384 U.S. 316 (1966). 
violated the standards of legality which previous cases had established for each type of offense. The Court's principal concerns were to disapprove the excessive reliance which the court of appeals had placed on FTC v. Gratz, ${ }^{91}$ and to emphasize the FTC's power to establish new categories of offenses. Particularly revealing is the statement that

it is now recognized in line with the dissent of Mr. Justice Brandeis in Gratz that the Commission has broad powers to declare trade practices unfair. This broad power of the Commission is particularly well established with regard to trade practices which conflict with the basic policies of the Sherman and Clayton Acts even though such practices may not actually violate these laws. ${ }^{92}$

This statement implies that the FTC also has power to declare conduct unfair for reasons other than its effect on competition.

The Court also emphatically approved the incipiency rationale of section 5 of the FTC Act: "The Commission acted well within its authority in declaring the Brown franchise program unfair whether it was full blown or not." ${ }^{23}$ How much competitive injury was necessary before the incipiency threshold was crossed remained vague. The Court mentioned that Brown was the second largest firm in the industry and that smaller competitors who did not offer the benefits available to Brown plan dealers (presumably because they could not afford to match Brown) were finding it difficult to retain those dealers as customers. The Court did not analyze in detail the effect of the Brown plan on other shoe manufacturers, but it may have thought this unnecessary because of its earlier examination and condemnation of the vertical foreclosure produced by Brown's merger with Kinney shoes. ${ }^{04}$ In future cases where the Court lias not had the fortuitous opportunity to have already studied the imdustry, it is difficult to predict the degree of injury which the Court will require to establish incipient lessening of competition.

\section{The Analogy to a Tying Agreement}

The significance of the Brown Shoe decision will be clearer if it is first determined how the Brown plan would have fared under other antitrust statutes. The application of other antitrust laws would depend upon how the Brown plan was conceptualized. The Commission viewed the plan as a tying agreement. However, the plan differed from the usual tying arrangement because the attractiveness of the tying product in Brown Shoe did not result from the product's dominant market position;

91253 U.S. $421 .(1920)$.

92384 U.S. at $320-21$.

93 Id. at 322 .

94370 U.S. 294, 302-03, 328-34 (1962). 
rather, it was attractive because it was free. The dealers paid nothing for the forms and merchandising aids; the rubber footwear was not made by Brown and was attractive to the dealers only because they could buy it at a reduced price. The court of appeals was evidently impressed by these differences.

It would appear, however, that the use of free articles or reduced prices to generate leverage for the tied product is proscribed by the statement in United States v. Loew's Inc. ${ }^{95}$ that "desirability to consumers" may constitute a substitute for dominance. ${ }^{96}$ In any event, where the "tying product" is free services the arrangement would fall outside the prohibition of section 3 of the Clayton Act, which prohibits the sale of product $X$ on condition that a competitor's product $Y$ not be purchased.97

The inapplicability of the Clayton Act for technical reasons would not preclude a Sherman Act prosecution, since tying agreements have been held to be per se violations of the Sherman Act. ${ }^{98}$ But the application of the Sherman Act to the Brown plan would appear strained. Exceptions to the rule that tying is a per se offense have been made where the tying agreement was not being used as a device to extend the seller's market power in one product to another product, ${ }^{99}$ or where the nature of the product required that it be tied to some other product in order to preserve quality. ${ }^{100}$ The Brown plan did not demonstrate "the vice of tying arrangements, [which] lies in the use of economic power in one market to restrict competition on the merits in another." ${ }^{\text {101 }}$ Brown did not manufacture any of the articles used for "tying," and apparently made little or no profit in selling them. Brown had "economic power" in the manufacture and sale of shoes, but the shoes were sold to any

05 United States v. Loew's, Inc., 371 U.S. 38 (1962).

06 Id. at 45. Had the tying product been Brown's shoes, the court of appeals could have relied on Brown Slıoe Co. v. United States, 370 U.S. 294 (1962). The Suprenie Court's analysis in that case suggested that this product had sufficient market appeal for it to restrain trade in any other product to which it might be tied. $I d$. at 331-32.

07 See Lessig v. Tidewater Oil Co., 327 F.2d 459, 469 n.24 (9th Cir.), cert. denied, 377 U.S. 993 (1964).

08 Northern Pac. Ry. v. United States, 356 U.S. 1, 6 (1958).

90 See, e.g., Crawford Transp. Co. v. Chrysler Corp., 235 F. Supp. 751 (E.D. Ky. 1962), aff'd, 338 F.2d 934 (6th Cir. 1964), cert. denied, 380 U.S. 954 (1965) (Defendant's requirement that its dealers ship only with small number of truckers to whom defendant had given contracts held not an illegal tying agreement, because Chrysler received no profit from the arrangement; it would appear, however, that Chrysler profited indirectly because the savings on transportation were passed on to the ultimate consunier and presumably increased Chrysler's sales.).

100 See, e.g., Susser v. Carvel Corp., 332 F.2d 505 (2d Cir. 1964), petition for cert. dismissed as improvidentiy granted, 381 U.S. 125 (1965); United States v. Jerrold Electromics Corp., 187 F. Supp. 545, 555-58 (E.D. Pa. 1960) (dictum), aff'd per curiam, 365 U.S. 567 (1961).

101 Northern Pac. Ry. v. United States, 356 U.S. 1, 11 (1958). 
dealer who wanted them without a requirement that he buy some other product to get them. This situation contrasts with that in Atlantic-Goodyear. Atlantic, although it did not manufacture TBA, engaged in the TBA business indirectly through the medium of the sales commission plan with Goodyear and received a substantial profit.

A hypothetical example will illustrate the defect in the analogy of the Brown plan to a tying agreement. The simplest form of a tying agreement would be if Brown sold its shoes on condition that the retail dealer buy some other product that Brown made or resold. If Brown offered a reduced price on shoes as part of a package sale with some other Brown product, that would also be treated as a forbidden tying agreement. ${ }^{102}$ In either of these examples Brown's economic power in the shoe market in being transferred to some less popular product. Under the Brown plan, however, this was not the case. The FTC's analysis would require that the merchandising aids and other benefits of the Brown plan be treated as a tying product rather than as part of a promotional effort to sell shoes.

\section{The Analogy to an Exclusive Dealing Arrangement}

The Brown plan could have been characterized as an exclusive dealing arrangement. This was apparently the view taken by the FTC hearing examiner. ${ }^{103}$ The usual form of such an arrangement is a promise from the dealer not to handle goods which conflict with those of the seller. The dealers typically demand in return that the seller refrain from selling to any other dealer within a certain territory and impose territorial restrictions on other dealers. ${ }^{104}$

The Supreme Court has stated that an exclusive dealership often serves legitimate business needs and is not illegal per se. ${ }^{105}$ It is, however, a restrictive device and its use will be forbidden whenever it tends substantially to lessen competition. ${ }^{106}$

In Brown Shoe, the total sales of all Brown plan outlets amounted

102 See Oxford Varnish Corp. v. Ault \& Wiborg Corp., 83 F.2d 764 (6th Cir. 1936) (seller offered reduced royalties on patented process if buyer bought all required materials from seller); Turner, supra note 70 , at 65 . The example in the text assumes that the difference in the package price could not be justified by cost savings. If the price cut reflected only the seller's savings, there would be no transfer of power from the more favored product to the less favored, and the package would not constitute a tying agreement. See United States v. Loew's, Inc., 371 U.S. 38, 53-54 (1952).

103 See Brown Shoe Co., Trade Reg. Rep. If 15705 (FTC Jan. 5, 1962).

104 E.g., White Motor Co. v. Umited States, 371 U.S. 505 (1963); Note, Restricted Channels of Distribution Under the Sherman Act, 75 HARv. L. REv. 795, 809-13 (1962). 105 Standard Stations, 337 U.S. 293, 306-07 (1949); See Tampa Elec. Co. v. Nashville Coal Co., 365 U.S. 320 (1961).

108 Tampa Elec. Co. v. Nashville Coal Co., supra note 103, at 333. 
to less than one per cent of the national shoe market. Only a part of those sales consisted of sales of Brown shoes, because the plan did not require dealers to sell only Brown shoes. In Tampa Elec. Co. v. Nashville Coal Co. ${ }^{107}$ the Supreme Court held that foreclosure of less than one per cent of the relevant market by a requirements contract did not violate section 3 of the Clayton Act.

The Commission maintained that the degree of injury to competition which was required for a section 5 violation was lower than for a Clayton Act violation, relying on its own decision in Luria Bros. \& Co. ${ }^{108}$ But the statements in Luria were only dicta, for the respondent's exclusive dealing agreements had increased its market share to 33.7 per cent-ample to invoke the Clayton Act. ${ }^{109}$

The Supreme Court's opinion gives little indication of how much injury will suffice to establish an incipient violation. Brown's proposed merger with Kinney Shoes was prohibited under section 7 of the Clayton Act because it would have given the combined firm five per cent of the national retail shoe market. ${ }^{110}$ Should this decision mean that the Brown plan, which gave Brown himited control of less than one per cent of this same market, is permissible? Tampa Electric does not stand for the proposition that any contract which forecloses less than one per cent of the market is automatically legal. There may be factors peculiar to the industry which render even such a small share a substantial threat to competition. ${ }^{111}$ However, upon analysis this does not appear to be the case with respect to the Brown plan. Unlike the twenty-year contract in Tampa Electric, the Brown plan contracts were frequently informal and subject to termination by either party at any time. Moreover, the threat of termination did not carry the same sting as it did for the gas station dealers in Atlantic-Goodyear. Brown continued to sell shoes to dealers who had terminated their Brown plan relationship; had Brown refused to do so, the dealer would have encountered little difficulty in acquiring shoes from other outlets without expensive change-over costs.

Instead of following the hine of analysis laid down in Tampa Electric, the Court relied on the same constructive coercion rationale which it used in the Atlantic-Goodyear case. The use of this rationale in Brown Shoe is questionable for two reasons. First, it does not appear from the facts that the dealers were coerced. They entered into the plan voluntarily

107365 U.S. 320 (1961).

108 TRADE REG. REP. II 16183, at 20986 (FTC Nov. 15, 1962).

109 Id. at 20994. In several regional markets the respondent's share had increased to between $50-75 \%$. Ibid.

110 Brown Shoe Co. v. United States, 370 U.S. 294 (1962).

111 See 365 U.S. at 334; Bok, The Tampa Electric Case and the Problem of Exclusive Arrangements Under the Clayton Act, 1961 SUP. Cr. Rev. 267, 285. 
and were free to leave it at any time. They apparently continued the relationship because they found it more profitable to do so, despite the necessity for replacing certain hines they preferred with shoes made by Brown. ${ }^{112}$ It is difficult to identify this contractual "quid-pro-quo" with the situation in Atlantic-Goodyear, where Atlantic alone received all the benefit of the sales commission plan and the dealers received nothing. Also, although the concept of coercion may be a convenient substitute for detailed analysis of the causes of a clearly restrictive pattern of behavior, the coercion should not be a substitute for the finding of the restriction itself.

\section{The Analogy to the Robinson-Patman Act}

The special benefits Brown gave to its dealers under the Brown plan do not fit precisely into any section of the Robinson-Patman Act. ${ }^{118}$ Yet taken as a group, they confer upon a selected class of purchasers numerous advantages not available to others. It appears therefore that the Coinmission might properly have followed the Grand Union doctrine and drawn an analogy between the special benefits of the plan and various sections of the Robinson-Patman Act.

Section 2(e) of the act ${ }^{114}$ forbids a seller to furnish services or facilities comrected with the sale or handling of his goods to one purchaser without furnishing proportionate benefits to all other purchasers. Failure to comply with this requirement is a per se offense, and the defendant does not have available the section $2(\mathrm{~b})$ defenses of cost justification or good faith meeting of competition. The accounting forms and business planning techniques of the Brown plan seem to fall within the prohibitions of this section. ${ }^{115}$ There might be some question, however, whether these services were sufficiently closely connected with the handhing of Brown

112 The Commission apparently thought that dealers did not remain in the Brown plan because they feared financial loss from cancellation, as did the dealers in Atlantic-Goodyear. Rather, they remained because they found it more profitable than independent operation, despite pressure to replace certain competing lines with less profitable Brown products. See Brown Shoe Co., Trade Reg. Rep. I 16316, at 21146 (FTC March 12, 1963). In the Brown-Kinney decision, however, the Supreme Court had descrihed Brown's control over its dealers in terms very similar to those used in Atlantic-Goodyear: "Brown reserved the power to terminate such franchise agreements on 30 days' notice. . . . Since the retailer was required, under this plan, to invest. his own resources and develop his good will to a sub. stantial extent in the sale of Brown products, the flow of which Brown could readily terminate, Brown was able to exercise sufficient control over these stores and departments to warrant their characterization as 'Brown' outlets . . ." 370 U.S. at 337 n.66. The Court adhered to this view in Brown Shoe. 384 U.S. at 317 n.2.

11349 Stat. 1526 (1936), 15 U.S.C. $\$ \S 13$ (a)-(f), 13a-c (1964).

11449 Stat. 1527 (1936), 15 U.S.C. $\$ 13($ e) (1964).

115 Cf. FTC v. Simphicity Pattern Co., 360 U.S. 55 (1959). 
shoes. But if "handling" is not arbitrarily limited to physical handling, there would seem to be no problem.

The sale of the rubber footwear at a discount presents more complex problems. If Brown Shoe sold these products to non-plan dealers at the regular price, this would constitute a classic violation of section 2(a) which forbids a seller "to discriminate in price between different purchasers of commodities of like grade and quality."116 But Brown apparently bought this kind of footwear solely for the purpose of selling it to Brown plan dealers. ${ }^{117}$

Arguably the sale of rubber footwear is analogous to the non-proportionate promotional allowances forbidden under section 2(d). The theory would be that if the dealers attracted customers by offering rubber footwear at reduced prices, some of those customers would also buy Brown products. The sale of the rubber goods would thus become an indirect form of advertising Brown shoes. ${ }^{118}$

On the other hand, the dealer might sell the rubber footwear at his usual price, in which case the effect of the arrangement would simply be to increase the dealer's profit. This was also the effect of the group insurance benefit contained in the plan, because the dealer obtained insurance for a lower premium than that available if purchased on an individual basis. Arguably, this result could be analogized to those cases which hold that when a promotional allowance is given without the seller requiring that the allowance be spent for promotion, and in fact it is not so spent, it is the equivalent of price discrimination under section $2(\mathrm{a})$. $^{119}$

From the above discussion, it is clear that the benefits given to Brown plan dealers are not prohibited by any specific words of the Robinson-Patman Act. However, when they are considered as a whole, they do violate the policy of that statute. The effect of prohibiting the Brown plan in its present form as a violation of the Robinson-Patman Act would have been different from the total abolition of the plan which resulted from the Supreme Court's decision. The suggested alternative would have left Brown Shoe free to offer extra benefits in proportion to the quantity of shoes bought by each dealer to which it sold. ${ }^{120}$ It should

11649 Stat. 1526 (1936), 15 U.S.C. § 13(a) (1964).

117 This practice might have been attacked indirectly, by bringing a Robinson-Patman Act procecding against Brown Shoe's seller if Brown Shoe was obtaining the benefit of a discriminatory price which it passed on to its dealers.

118 Cf. R. H. Macy Co. v. FTC, 1964 Trade Cas. \I 70998 (2d Cir.).

119 Rowe, Price Discrimination Under the Robinson-Patman ACT 17 (1964 Supp.). 120 Sections $2(\mathrm{~d})$ and $2(\mathrm{e})$ prohibit only the making of non-proportionate payments for facilities or promotional allowances. FTC v. Simplicity Pattern Co., 360 U.S. 55 
be recognized that the former Brown plan dealers would still receive the lion's share of the benefits because they were for the most part the larger and more successful dealers. ${ }^{121}$ There is also some evidence that the other three major shoe manufacturers had similar plans and that smaller manufacturers could not afford such a plan.

If the ability of Brown and the other large shoe companies to adopt such a plan resulted from their greater productive efficiency, and if the savings from that efficiency were to be passed on to the consumer in the form of reduced prices rather than spent for increased promotional outlay, it is obvious that this behavior is desirable and is not a violation of any antitrust law. ${ }^{122}$ Whether this should be equally true with regard to increased promotional expenses has recently been questioned, ${ }^{123}$ but the issue is unsettled. The Brown Shoe decision, however, seems to make it a new per se offense for a company to employ its economic power for increased promotion.

\section{B. Mergers Under Section 5}

The preceding discussion of FTC v. Browen Shoe Co. has criticized the use of section 5 of the FTC Act to create new per se antitrust violations when the conduct in question does not constitute or is not analogous to a per se violation of the Clayton or Sherman Acts. There is some indication that the FTC is following this same course in its actions against vertical integration in the cement industry. Before examining the Commission's actions in this area in detail, it is necessary to consider the extent to which under present law vertical mergers are analogous to per se violations.

It appears that any horizontal merger is illegal under section 7 of the Clayton Act if it involves one of the leading firms in an industry, ${ }^{124}$ or if the combined market share of the firms exceeds five per cent of the relevant market. ${ }^{25}$ With respect to vertical mergers the law is less

(1959) (dictum); Atlanta Trading Corp v. FTC, 258 F.2d 365 (2d Cir. 1958). The Robinson-Patman analogy seems consistent with United States v. Loew's, Inc., 371 U.S. 38 (1962), which permitted cost justified discounts for movies booked as a package.

121 See TrADE REg. ReP. II 18316, at 21146.

122 Kaysen \& TURner, ANTITrust PoItCy 11-14 (1959).

123 See Procter \& Gamble Co., Trade Reg. Rep. I 16674 (FTC Nov. 26, 1963), rev'd, 358 F.2d 74 (6th Cir.), cert. granted, 35 U.S.L. WeEx 3136 (U.S. Oct. 18, 1966); Turner, Conglomerate Mergers and Section 7 of the Clayton Act, 78 Hanv. L. Rev. 1313, 1332-37 (1965).

124 See, e.g., United States v. Continental Can Co., 378 U.S. 441 (1964); United States v. Aluminum Co. of America, 377 U.S. 271 (1964).

125 See, e.g., United States v. Pabst Brewing Co., 384 U.S. 546 (1966); United States v. Von's Grocery Co., 384 U.S. 270 (1966); cf. United States v. Philadelphia Nat'1 Bank, 374 U.S. 321, 363-66 (1963), stating that a merger which gave the parties $30 \%$ of the relevant market was presumptively illegal. The more recent opimions have held illegal 
clear. Brown Shoe Co. v. United States,${ }^{126}$ is the most recent case in which the Supreme Court set forth the proper approach in analyzing a vertical merger. The Court there required that, except where the share of the market foreclosed approached monopoly proportions, "only a further examination of the particular market-its structure, history and probable future-can provide the appropriate setting for judging the probable anticompetitive effect of the merger." ${ }^{\prime 127}$ Taken at face value these words preclude the treatment of most vertical mergers as per se offenses. Some commentators have asserted, however, that even in the Brown-Kinney decision itself the Court reached a result inconsistent with this analytical framework. ${ }^{128}$

The Supreme Court's per curiam affirmance of Alcoa-Cupples ${ }^{129}$ also suggests that the Court may be on the verge of announcing that vertical mergers are illegal per se. ${ }^{130}$ At the time of its merger with Alcoa, Cupples was the leading fabricator of aluminum curtain wall, but its market share was only about sixteen per cent. The merger did not increase any company's market share, nor did the industry exhibit a trend toward concentration.

The government's case rested principally on certain special competitive advantages which the merger would brimg to Cupples: the support of Alcoa's "deep purse;" the use of Alcoa's name which would impress contractors with the rehability of Cupples in comparison with other bidders; and the favored position that Cupples would allegedly enjoy in supplying aluminum to Alcoa-controlled high-rise real estate developments. All of these and similar advantages tended to show only that customers of the merged firm might favor it in a close decision, and that its competitors might be discouraged from competing for at least some of the business. But this theory was highly speculative, and as yet it has

mergers producing much smaller market shares than $30 \%$, although the percentages may sometimes appear higher because the definition of the market has been manipulated. See Umited States v. Grinnell Corp., 384 U.S. 563, 587-93 (1966) (dissent) ; FTC v. Mytinger \& Casselberry, 301 F.2d 534, 542-43 (D.C. Cir. 1962) (dissent).

126370 U.S. 294 (1962) [hereinafter referred to as Brown-Kinney to avoid confusion with FTC v. Brown Shoe Co., 384 U.S. 316 (1966)].

127 Id. at 322 n.38, 329.

128 Cook, Merger Law and Big Business: A Look Ahead, 40 N.Y.U.L. Rev. 710, 712 (1965); Hall \& Phillips, Antimerger Criteria: Power, Concentration, Foreclosure and Size, 9 VIIL. L. REV. 211, 221-23 (1964).

120 United States v. Aluminum Co. of America, 233 F. Supp. 718 (E.D. Mo. 1964), aff'd ment., 382 U.S. 12 (1965).

130 Such a rule need not be absolute. Specific exceptions could be made when the acquired company was on the verge of failure or when two small companies merged to compete nore effectively with larger competitors. See Brown Shoe Co. v. United States, 370 U.S. 294, 331 (1962) (dictun1). These exceptions are themselves per se in character. The rule would exclude, however, any economic analysis of the industry in question. 
not been supported either by economic theory or by actual developments in the wake of analogous mergers. ${ }^{131}$ In the light of the evidence of injury to competition accepted by the Court in Alcoa-Cupples, it is at least arguable that the Court has, without expressly so stating, extended the per se rule to all vertical mergers.

The Federal Trade Commission has only recently begun to proceed against mergers under section 5 of the FTC Act. ${ }^{132}$ In a complaint filed against Ideal Cement Co., ${ }^{133}$ the Commission based its action on section 5 , rather than on section 7 of the Clayton Act. This decision apparently reflects the Commission's belief that section 5 applies to mergers in which the threat to competition does not yet reach the Clayton standards of incipiency. Ideal, allegedly the first or second largest manufacturer of portland cement in the nation, acquired the stock of the largest readymix concrete company in Houston, Texas. The complaint alleged that within the previous year companies having more than forty per cent of the concrete market in Houston had been acquired by portland cement manufacturers, and that this had substantially lessened competition in at least three relevant markets: the entire nation, the State of Texas, and the City of Houston.

Portland cement is sold nationally, and the complaint does not reveal any reason why Houston or Texas would be meaningful submarkets in which to measure the effect of the merger upon competition within the cement industry. ${ }^{134}$ Though no percentage shares of the national market are indicated in the complaint, it seems unlikely that the loss of

131 Similar fears were expressed by the FTC in ordering Procter \& Gamble to divest itself of Clorox, but after ten years' combined operation, Clorox's share of the liquid bleach market is virtually unchanged. In reversing that decision, the court of appeals said that the basis for the Commission's view was nothing more than a conviction that bigness was inherently bad and that for a big company to acquire a smaller one in any field, regardless of whether competitors were foreclosed, was a per se offense. Procter \& Gamble Co. v. FTC, 358 F.2d 74, 84 (6th Cir.), cert. granted, 35 U.S.L. WeEK 3136 (U.S. Oct. 18, 1966).

132 The Commission did 50 in Foremost Dairies, Trade Rac. Rep. II 15877 (FTC April 30, 1962). Section 5 was used there apparently only because some of the acquired firms were partnerships; $\S 7$ of the Clayton Act applies only to the acquisition of corporations.

183 Trade Reg. Rep. II 17430 (FTC Jan. 26, 1966).

134 See United States v. Grinnell Corp., 384 U.S. 563, 586-90 (1966) (dissent); Crown Zellerbach Corp. v. FTC, 296 F.2d 800, 816-18 (9th Cir. 1961) (three Pacific Coast states constituted area in which "most active and extensive competition occurred" and which was "subject to common economic forces ... Which set it apart from other areas in the west"); Eire Sand \& Gravel Co. v. FTC, 291 F.2d 279 (3d Cir. 1961); but see United States v. Pabst Brewing Co., 304. U.S. 546, 549-50 (1966) ("Proof of the section of the country where the anti-competitive effect exists is entirely subsidiary to the crucial question ... which is whether a merger may substantially lessen competition anywliere in the United States."). 
part of the Houston market to Ideal could produce a significant amount of foreclosure upon other cement manufacturers in the national market.

The merger's effect on competition among the ready-mix concrete companies is unclear, but there is nothing to indicate that any of these companies will increase its share of the ready-mix concrete market as a result of the merger. The Commission apparently believes that the industry is experiencing a series of mergers by which the local concrete companies are coming under the control of the national supphers. ${ }^{135}$ If this is correct, what were once small independent companies will now be divisions of larger companies. This need not, however, result in any increased concentration within the ready-mix concrete industry itself.

In Procter \& Gamble Co., ${ }^{136}$ the Commission claimed that the acquired company, Clorox, would enjoy special competitive advantages stemming from parent Procter \& Gamble's quantity purchases of advertising. This theory would not apply to the ready-mix concrete industry, however, because advertising does not play an important role therein. The integrated cement-concrete companies, however, would enjoy the benefit of strong financing. This competitive situation might tend to discourage the entry of new firms into the concrete business, ${ }^{137}$ even though the amount of capital required to purchase the necessary plant and equipment is unlikely to be increased by the pattern of mergers. Even if the mergers did tend to raise entry barriers, this would not appear to be a serious threat to competition in an industry which has relatively little horizontal concentration. ${ }^{138}$

Apparently the Commission's theory is that if the cement companies continue their pattern of acquiring ready-mix companies in the major metropolitan areas, they will produce a cunnulative foreclosure effect on those cement producers which are too small to adopt the same policy of vertical integration. If the geographical submarket is properly defined, ${ }^{139}$ the challenged merger would not in itself produce sufficient foreclosure

135 See remarks of Paul R. Dixon, Chairman of the FTC, Trade REg. REP. $\mathbb{5 0 1 4 9}$ (July 18, 1966).

136 TrADE REG. RER. If 16673 (FTC Nov. 26, 1963), rev'd, Procter \& Gamble Co. v. FTC, 358 F.2d 74 (6th Cir. 1966), cert. granted, 35 U.S.L. WEEK 3136 (U.S. Oct. 18, 1966). Procter \& Gamble, a leading manufacturer of household detergents and cleansers had acquired the stock of Clorox Co., a manufacturer of hquid chlorine bleach. The hquid bleach industry contains hundreds of small local firms; Clorox is the only brand sold nationwide (although Purex competes with it in most sections of the country), and it holds about $60 \%$ of the market.

${ }^{137}$ Cf. United States v. Aluminum Co. of America, 233 F. Supp. 718, 727-28 (E.D. Mo. 1964), aff'd per curiam, 382 U.S. 12 (1965).

138 But see United States v. Von's Grocery Co., 384 U.S. 270 (1966); Reynolds Metals

Co. v. FTC, 309 F.2d 223 (D.C. Cir. 1962).

139 See note 134 supra. 
to violate section 7 of the Clayton Act. ${ }^{140}$ But the FTC argues, as it did in Foremost Dairies, ${ }^{141}$ that it should not have to wait until a gradual series of mergers has already greatly increased concentration in an industry. Rather, the Commission asserts the right to challenge the concentration-by-merger process at an early stage.

In the context of vertical mergers the incipiency rationale has a much more sweepmg application than when it is used to justify the suppression of competitive practices cleemed analogous to per se offenses. Although one may speculate that vertical mergers have virtually been given that status by implication, ${ }^{142}$ the Supreme Court has not openly embraced this conclusion. Moreover, the Court has had far less experience in reviewing the economic effects that typify vertical mergers than it has with respect to horizontal mergers. Certainly the effects of vertical mergers do not uniformly meet the standard for declaring a practice illegal per se which was laid down in Northern Pac. Ry v. United States. ${ }^{143}$ The FTC apparently recognized this in dismissing Clayton Act charges brought against other cement company-concrete company mergers on the ground that probable injury to competition had not been shown. The use of section 5 of the FTC Act to attack a similar merger in Ideal Cement raises the suspicion that the Commission has abandoned this view and is now contending that any merger between a leading cement manufacturer and any concrete producer is illegal.

\section{CONCLUSION}

FTC v. Brown Shoe Co. ${ }^{144}$ and possibly also the complaint in Ideal Cement Co. ${ }^{145}$ suggest that the Commission may freely use section 5 of the FTC Act to create new per se antitrust violations. The availability of this power raises questions regarding the proper relationship of per se rules to economic analysis in FTC proceedings.

One of the principal justifications for the creation of the FTC was the theory that an administrative agency could develop a body of expert knowledge in the complex area of antitrust law. ${ }^{146}$ The average district court judge could not be expected to be sufficiently familiar with this

140 Section 7 of the Clayton Act requires that an illegal merger be shown to pose a probable threat of a substantial lessening of competition. This requirement is not met by showing that a given merger will foreclose a de minimus share of the market. Brown Shoe Co. v. United States, 370 U.S. 294, 329 (1962) (dietum).

141 Trade Reg. Rep. II 15877 (FTC April 30, 1962).

142 See text accompanying notes $125-32$, supra.

143356 U.S. 1 (1958).

144384 U.S. 316 (1966).

145 Trade Reg. Rep. II 17430 (FTC Jan. 26, 1966).

146 Markham, The Federal Trade Commission's Use of Economics, 64 Colum. L. Rev. 405, 405-06 (1964). 
area of the law. ${ }^{147}$ The Commission at one time interpreted this theory of expertise as requiring it to base its decisions on extensive economic analysis of the industry and the probable future effect of the practice being investigated..$^{148}$

The use of such an approach by the Commission is subject to the same objections that have been directed against its use by the courts. It burdens the courts with lengthy trials ${ }^{149}$ and the litigants with heavy costs. ${ }^{100}$ It produces vaguely formulated rules, so that lawyers are unable to furnish their clients with accurate counsel in advance of a proposed action. ${ }^{151}$

Faced with these objections the courts have tended to favor the development of workable per se rules. The Commission might be able to ameliorate the disadvantages of an elaborate rule of reason proceeding by employing its expertise and the flexibility of an administrative proceeding. Nevertheless, it has been suggested that the Commission should not adopt such a policy, because to do so would create dual standards of enforcement. ${ }^{152}$ This suggestion assumes that if the FTC relied on extensive economic analysis and the courts did not, different standards of illegality would develop. Hence, the outcome of a case might depend on the fortuitous factor of whether the Commission or the antitrust division first brought proceedings..$^{153}$

These arguments against extensive use of economic analysis assume that the precedential value of any given decision is limited, since the reasonableness of a particular restraint depends on the entire context in which it is operating. If it is true that economic analysis of the effects of the defendant's conduct in one case would be of hittle use in resolving future disputes, then such a technique would be of questionable value in providing realistic guidelines for business decisions. However, an alternative approach is possible which would combine the merits of economic analysis with the benefits of workable per se rules. This approach would

147 Elman, Rulemaking Procedures in the FTC's Enforcement of the Merger Law, 78 HARv. L. REv. 385, 387 (1964).

148 Pillsbury Mills, Inc., 50 F.T.C. 555,565 (1953).

140 See United States v. Grinnell Corp., 236 F. Supp. 244, 246-48 (D.R.I. 1964), aff'd and remanded for modification of decree, 384 U.S. 563 (1966).

100 United States v. Arnold, Schwinn \& Co., 237 F. Supp. 323 (N.D. TIl. 1965), prob. juris. noted, 382 U.S. 936 (1965) (No. 611, 1965 Term; renumbered No. 25, 1966 Term). The court estimated the total out-of-pocket litigation expense to the parties at $\$ 1,000,000$. 237 F. Supp. at 332.

161 Elman, supra note 147 , at 386.

162 Markham, supra note 146, at 411-14; cf. Crown-Zellerbach Corp. v. FTC, 296 F.2d 800, 815 n.11 (9th Cir. 1961).

153 Ibid. This would especially be true with respect to the Clayton Act, which is enforced by both the FTC and the antitrust division of the Justice Department. 
aim toward the eventual formulation of per se rules which are determined on the basis of an adequate investigation into the economic justifications and effects of a particular practice. In other words, an economic analysis can be used as the essential framework for the creation of a per se rule. ${ }^{\mathbf{1 5 4}}$

The Supreme Court has asserted that it treats as per se violations those "agreements or practices which because of their pernicious effect on competition and lack of any redeeming virtue are conclusively presumed to be unreasonable and therefore illegal without elaborate inquiry as to the precise harm they have caused or the business excuse for their use."155 Before the Supreme Court will make such a conclusive presumption, however, it must be apprised of the actual and potential effect on competition of the practice in question. ${ }^{158}$

Cases like Brown Shoe and Ideal Cement create a legitimate doubt that the FTC is following the mandate of the Supreme Court with respect to the development of per se rules. Instead, the FTC appears to be creating those rules solely on the basis of its broad grant of authority under section 5 of the FTC Act. The Supreme Court has given its blessing to this practice; ${ }^{157}$ there is no longer any question that the FTC has the necessary power. The important question to be answered now is how that power should be used.

If cases under the Clayton and Sherman Acts have already developed a substantive standard of illegality which has crystallized into a per se rule for a particular practice, it appears reasonable that the FTC should be able to apply that rule in a proceeding under section 5 of the FTC Act. This conclusion is equally true even if the practice involved could not be reaclied under another statute. If the other statute is not applicable for technical reasons, it is consonant with the purposes of section 5 to use it to fill the gap. ${ }^{158}$ The terms of the other statute may require a finding of probable injury to competition, a requirement which can be avoided under section 5 by invoking the incipiency rationale. ${ }^{160}$ If the conduct in question is analogous to a per se offense, however, the use of section 5 to eliminate this requirement does not change the result, because competitive injury is presumed for per se offenses.

The use of section 5 to promulgate per: se rules requires a different

154 See Markham, supra note 146 at 410.

155 Northern Pac. Ry. v. United States, 356 U.S. 1, 5 (1958).

158 White Motor Co. v. United States, 372 U.S. 253, 263 (1963).

${ }^{157}$ See FTC v. Brown Shoe Co., 384 U.S. 316, 320-22 (1966); Atlantic Ref. Co. v. FTC, 381 U.S. 357, 367-68; Klaus, supra note 69, at 925-26.

158 Oppenheim, Guides to Harmonizing Section 5 of the Federal Trade Conmission Act with the Clayton and Sherman Acts, 59 MicH. L. REv. 821, 841 (1961).

169 FTC v. Brown Shoe Co., 334 U.S. 320, 322 (1966); FTC v. Cement Institute, 333 U.S. 683, 720-21 (1948). 
approach when the courts either have not had enough experience with a practice to declare it a per se violation or have affirmatively declared that it is not a per se violation. Some members of the Commission have recognized this. Commissioner Elman has suggested that the Commission should make greater use of rule-making procedures to gather the facts needed to frame appropriate rules for controlling business practices when their effects are not yet well understood. ${ }^{100}$

This appears to be the policy that the Commission is following in attempting to regulate vertical mergers in the cement industry. Both rule-making and adjudicative procedures are being employed at the same time. ${ }^{101}$ The Chairman of the Commission has said in support of this procedure that, "the rule-making procedure will help develop "legislative facts which will help the Commission decide questions of law, pohicy and discretion"; 182 but the Commission would continue to attack those mergers that appear clearly illegal under present pohcy.

The relative advantages and disadvantages of rule-making compared with adjudicative procedures is a topic beyond the scope of this Comment. ${ }^{103}$ It would be unfortunate, however, if the functions of gathering facts and framing rules were to be carried out solely through rule-making procedures. The Brown Shoe and Ideal Cement cases indicate that the Commission is in effect developing new per se rules in adjudications under section 5 of the FTC Act. If this is the case, the Commission should employ a thorough economic analysis in each adjudication until sound per se rules can be formulated. Such a policy would increase the likehhood that these per se rules would effectively control the restrictive effects of a given practice without unduly impeding the functioning of the businesses involved.

David Alan Leipziger

160 Elman, supra note 147 , at 390-91.

101 Trade REG. ReP. II 50149 (July 18, 1966).

162 Id. at 55186 .

103 See generally Shapiro, The Choice of Rulemaking or Adjudication in the Development of Administrative Policy, 78 HARV. L. REv. 921 (1965). 